\title{
ПРО НЕОБХІДНІСТЬ ОЦІНЮВАННЯ РІВНЯ ЕМОЦІЙНОГО СТРЕСУ ПРИ ПРОГНОЗУВАННІ ВИНИКНЕННЯ ІНСУЛЬТУ
}

\author{
О. Ю. Азархов ${ }^{1}$, В. В. Сєргєєва ${ }^{2}$, О. В. Бєлоусова ${ }^{2}$ Н. О. Шеремета ${ }^{3}$ \\ ПЗ «Санаторій «Металург» ${ }^{1}$ \\ Вінницький національний технічний університет ${ }^{2}$ \\ Вінницька обласна психоневрологічна лікарня ім. О. І. Ющенка
}

В статті розглянуто різні види стресів та емоційних станів людини та їх вплив на прогнозування виникнення інсульту. Досліджене суб'єктивне оцінювання стресового стану лікарями та пацієнтами.

Ключові слова: стрес, емоції, інсульт, оцінювання рівня стресу.

\section{О НЕОБХОДИМОСТИ ОЦЕНИВАНИЯ УРОВНЯ ЭМОЦИОНАЛЬНОГО СТРЕССА ПРИ ПРОГНОЗИРОВАНИИ ВОЗНИКНОВЕНИЯ ИНСУЛЬТА}

\author{
А. Ю. Азархов ${ }^{1}$, В. В. Сергеева ${ }^{2}$, О. В. Белоусова ${ }^{2}$, Н. А. Шеремета ${ }^{3}$ \\ ЧУ «Санаторий «Металлург»" \\ Винницкий национальный технический университет ${ }^{2}$ \\ Винницкая областная психоневрологическая больница им. А. И. Ющенко
}

\begin{abstract}
В статье рассмотрены различные виды стрессов и эмоциональных состояний человека и их влияние на прогнозирование возникновения инсульта. Исследовано субъективное оценивание стрессового состояния врачами и пациентами.
\end{abstract}

Ключевые слова: стресс, эмоции, инсульт, оценивание уровня стресса.

\section{THE NEED OF THE EMOTIONAL STRESS LEVEL ESTIMATING IN STROKE FORECASTING}

\author{
O. Yu. Azarkhov', V. V. Sierhieieva ${ }^{2}$, O. V. Bielousova ${ }^{2}$, N. O. Sheremeta ${ }^{3}$ \\ "Sanatorium "Metalurg"1 \\ Vinnytsia National Technical University ${ }^{2}$ \\ Vinnytsia Regional Psycho-Neuroiogical Hospital named after O. I. Yushchenko ${ }^{3}$
}

The article deals with various kinds of stress and emotional state and their influence on the prediction of apoplectic stroke. The subjective evaluation of the stress state of doctors and patients was investigated.

Key words: stress, emotion, stroke, stress level evaluation.

Вступ. Стрес за характером походження поділяють на фізіологічний, викликаний надмірним фізичним навантаженням; психологічний, зумовлений складними стосунками $з$ оточуючими; інформаційний, породжений надмірністю, недостатністю або безсистемністю життєво важливої інформації; управлінський, зумовлений великою відповідальністю за прийняті рішення; емоційний, який проявляється в ситуаціях загрози чи небезпеки [1] (рис. 1).

Стреси можуть бути гострі або шокові, що викликані різними екстремальними ситуаціями: хронічні, () О. Ю. Азархов, В. В. Сєргєєва, О. В. Белоусова, Н. О. Шеремета що припускають наявність постійного значного фізичного й морального навантаження на людину, і психосоціальні.

Гострий стрес розвивається миттєво з обов'язковим включенням нервової, симпато-адреналової, серцево-судинної систем і системи гіпофіз-кора надниркових зазолз. В перші хвилини виникнення гострого стресу реєструються його основні прояви, які зачіпають нервову і серцево-судинну системи. Хронічний стрес виникає при тривалій чи повторній взаємодії як сильних, так і відносно слабких стресорів. 
Puc. 1. Класифікація стресу.

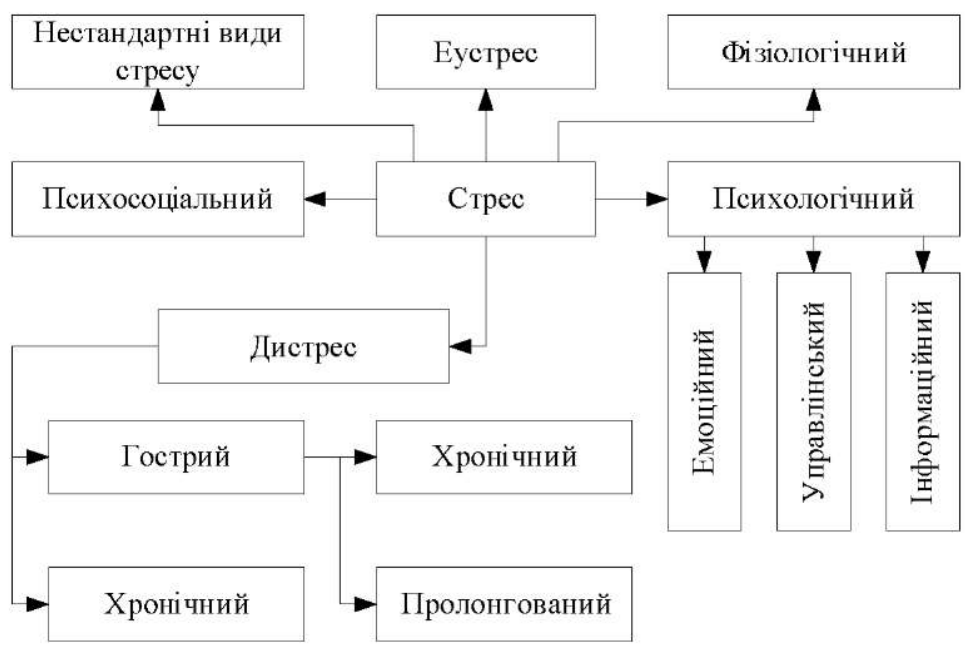

Постановка проблеми. Характер стресової реакції, що призводить до адаптації та хвороби, визначається різноманітними факторами: за модальністю - $є$ позитивним і негативним, конструктивним та деструктивним [1].

Окремо виділяють такі різновиди стресових станів як фрустрація та посттравматичний стрес. Стрес буває біологічний та патологічний, для якого характерні психосоматичні розлади, та нестандартні види стресу [2].
Емоції розрізняють за модальністю, зокрема - за знаком, за інтенсивністю, тривалістю, глибиною, генетичним походженням; складністю (прості і складні); умовами виникнення (статичні-астенічні); формою розвитку; за рівнями прояву в будові психічного (вищі-нижчі); за психічними процесами, з якими вони пов'язані; за потребами (інстинктами), за предметним змістом і направленістю (рис. 2).

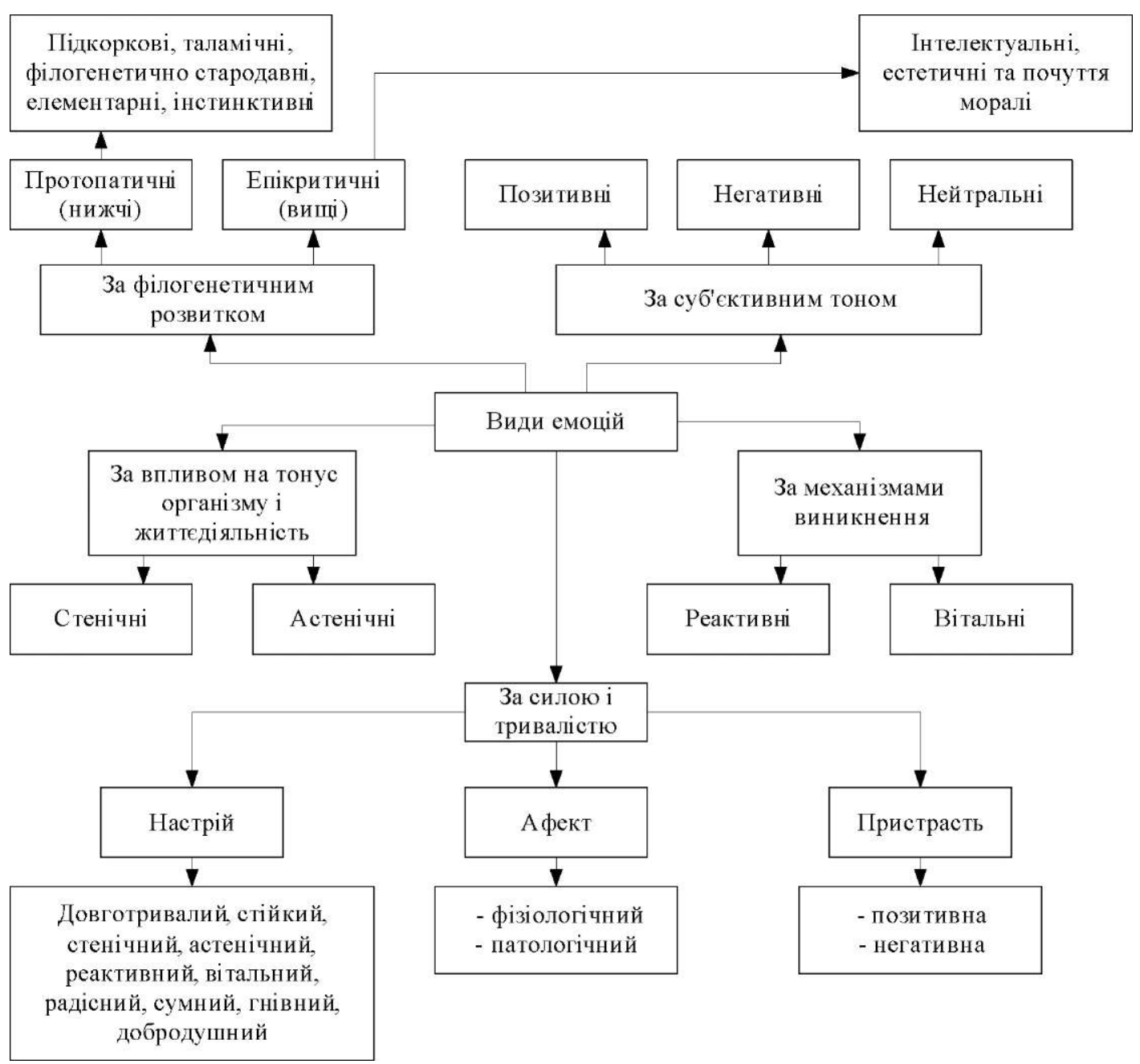

Pис. 2. Класифікація емоцій. 
Розглянемо докладніше запропоновану класифікацію. I. В людини вищі емоції переважають над нижчими.

II. За суб'єктивним тоном (сприймаються як суб'єктивно приємні, неприємні чи нейтральні) емоції поділяються на позитивні, негативні та нейтральні.

III. За впливом на тонус організму і життєдіяльність емоції бувають:

1) стенічні (підвищують тонус організму - від грецького < «stenos» - сила);

2) астенічні (знижують тонус організму «аstenos» - слабкість).

Емоції виражаються в стенічній та в астенічній формах залежно від типу нервової системи і вольових якостей людини.

IV. За механізмами виникнення.

Емоції виникають на основі внутрішніх потреб (ендогенний шлях) і внаслідок зовнішніх подразників чи пізнавання суб'єктом певних подразнень зовнішнього середовища (екзогенний шлях), тобто на основі механізмів пам'яті. Зовнішні впливи суттєво змінюють емоції, які виникли ендогенно.

1. Реактивні - виникають в якості реакції на зовнішній стимул.

2. Вітальні - переживання, пов'язані зі зміною біотонусу організму та функціонування систем, які беруть участь у реалізації емоційних реакцій.

V. За силою і тривалістю (див. рис. 2):

1. Настрій - це відносно слабкий емоційний стан, що захоплює на деякий час всю особистість і відображається на діяльності та поведінці людини. Настрій є довготривалим, стійким, може продовжуватись днями, тижнями, місяцями і охоплювати цілий період життя людини. Він буває стенічним або астенічним, реактивним чи вітальним, радісним чи сумним, гнівним чи добродушним і викликається різними обставинами та фізичним самопочуттям.

2. Афект - це короткочасна бурхлива емоційна реакція на зразок «емоційного вибуху», що супроводжується руховим перезбудженням або викликає заціпеніння руху і загальмованість мови (відчай, страх):

а) фізіологічний афект: викликається сильними подразниками у людей 3 нервовою системою неурівноваженого типу з переважанням процесів збудження.

б) патологічний афект: виникає на грунті органічної патології головного мозку, що поєднується 3 сутінковим розладом свідомості і супроводжується агресивними, руйнівними діями у відповідь на будьякий зовнішньо незначний чинник з подальшим анамнезуванням подій.

3. Пристрасть - сильне, стійке і глибоке почуття, зумовлене певними інтересами і діяльністю, яке за- хоплює всю людину і підкоряє собі основну спрямованість їі думок і дій. За спрямованістю є позитивною і негативною.

Емоції виконують функцію оцінки, що є опосередкованим продуктом мотиваційної значимості відображених предметів [3, 4].

Здатність емоцій порушувати цілеспрямовану діяльність стала основою теорій, які підкреслюють дезорганізаційну функцію емоцій, згідно з якими порушення діяльності є не прямим, а побічним проявом емоцій.

Основна частина. Поняття «стрес» в сучасній психології та медицині включає в себе уявлення про зв'язки стресу із навантаженням на біологічні, психологічні та соціально-психологічні системи. Стрес $є$ фізіологічним синдромом неспецифічних реакцій організму на пред'явлені до нього потреби. При емоційному стресі вплив психічних стресорів опосередкований через складні психічні процеси, які забезпечують оцінку стимулу і зіставлення його $з$ попереднім досвідом. Стимул набуває характеру стресора у випадку, коли в результаті психологічної обробки стимулу виникає почуття загрози. Суб'єктивне відношення до стимулу, особистісні особливості характеру когнітивних процесів і психічного стану представляють собою важливий психологічний механізм і визначають індивідуальну значимість стресора.

Діяльність працівників ризиконебезпечних професій обумовлює необхідність вирішення таких задач: профілактика небажаних психічних станів; вчасна розрядка надлишкової емоційної напруженості, стресових реакцій та екстреної мобілізації вольових ресурсів; формування захисних механізмів психічної адаптації, регулювання рівня стресу, що в кінцевому результаті забезпечує стан високої працездатності.

Із наведеного переліку видно, що вирішення практично будь-якої із задач пов'язано ще із однією проблемою, а саме $з$ визначенням або оцінюванням в кількісних та якісних показниках рівня емоційного стресу. I якщо ситуація 3 якісними показниками $є$ достатньо інформаційно забезпеченою, то кількісні показники практично відсутні.

Відомо, що емоційний стрес є однією із причин виникнення інсультів, тому виявлення психічних адаптаційних механізмів, що виникають у людини в умовах психологічної напруги, та встановлення особливостей зв'язку цих механізмів з психічним станом особистості запобігає прояву подальших психічних розладів. Формування психічних захистів забезпечує психічну рівновагу суб'єкта, знижує рівень тривоги i напруження, що в кінцевому результаті зменшує ризик виникнення інсульту. 
Нами була досліджена група хворих з ризиком розвитку інсульту в загальній кількості 126 осіб. Із них чоловіків було 76 осіб, жінок - 50 осіб. Віковий ценз складав від 45 до 70 років. Ризик виникнення інсульту був обумовлений різним ступенем тривоги, неврозами, соматовегетативними розладами, страхом, депресіями та їх поєднаним впливом.
Хворим було запропоновано оцінити рівень стресу за їх власними відчуттями в діапазоні $0 \div 1$. Аналогічне завдання було поставлене перед лікарями неврологами, невропатологами і психіатрами, які мали різний рівень професійної підготовки, стаж і досвід роботи.

Отримані результати були класифіковані за відповідними ознаками і представлені в таблицях 1 та 2.

Таблиця 1. Розподіл суб'єктивного оцінювання хворими рівня стресу залежно від вікового цензу і статевої ознаки

\begin{tabular}{|c|c|c|c|c|c|c|c|}
\hline \multirow{2}{*}{ № 3/П } & \multirow{2}{*}{\multicolumn{2}{|c|}{ Кількість і статевий розподіл }} & \multicolumn{4}{|c|}{ Вік хворих (роки) } & \multirow{3}{*}{$\begin{array}{c}\text { Всього } \\
76 \\
\end{array}$} \\
\hline & & & $45-50$ & $51-55$ & $56-60$ & $61-70$ & \\
\hline \multirow{2}{*}{1} & 76 & чол. & 14 & 21 & 23 & 18 & \\
\hline & усереднений діапазон оцінок стресу & & $0,54-0,61$ & $0,59-0,68$ & $0,63-0,78$ & $0,72 \div 0,96$ & \\
\hline \multirow{2}{*}{2} & 50 & жін. & 8 & 14 & 17 & 11 & 50 \\
\hline & усереднений діапазон оцінок стресу & & $0,5-0,57$ & $0,52-0,6$ & $0,62-0,75$ & $0,7 \div 0,9$ & \\
\hline
\end{tabular}

Таблиця 2. Розподіл суб'єктивного оцінювання лікарями рівня стресу пацієнтів залежно від вікового цензу і статевої ознаки

\begin{tabular}{|c|c|c|c|c|c|c|c|}
\hline \multirow{2}{*}{ № $3 / \Pi$} & \multirow{2}{*}{\multicolumn{2}{|c|}{$\begin{array}{c}\text { Кількість і статевий } \\
\text { розподіл }\end{array}$}} & \multicolumn{4}{|c|}{ Вік хворих (роки) } & \multirow{3}{*}{$\begin{array}{c}\text { Всього } \\
76 \\
\end{array}$} \\
\hline & & & \multirow{2}{*}{$\begin{array}{c}45-50 \\
14\end{array}$} & \multirow{2}{*}{$\begin{array}{c}51-55 \\
21 \\
\end{array}$} & \multirow{2}{*}{$\begin{array}{c}56-60 \\
23 \\
\end{array}$} & \multirow{2}{*}{$\begin{array}{c}61-70 \\
18 \\
\end{array}$} & \\
\hline \multirow{4}{*}{1} & 76 & чол. & & & & & \\
\hline & \multirow{3}{*}{$\begin{array}{c}\text { неврологи - } \\
3 \text { особи; } \\
\text { невропатологи - } \\
3 \text { особи; } \\
\text { психіатри - } \\
3 \text { особи }\end{array}$} & $\begin{array}{c}\text { Середній } \\
\text { стаж } \\
\text { роботи } \\
\text { (роки) 1-3 }\end{array}$ & $0,49-0,56$ & $0,52-0,6$ & $0,58-0,64$ & $0,67-0,85$ & \\
\hline & & $4-7$ & $0,51-0,55$ & $0,54-0,62$ & $0,6-0,68$ & $0,69-0,88$ & \\
\hline & & $8-10$ & $0,52-0,54$ & $0,57-0,64$ & $0,61-0,72$ & $0,74-0,89$ & \\
\hline \multirow{4}{*}{2} & 50 & жін. & 8 & 14 & 17 & 11 & 50 \\
\hline & \multirow{3}{*}{$\begin{array}{c}\text { неврологи - } \\
3 \text { особи; } \\
\text { невропатологи - } \\
3 \text { особи; } \\
\text { психіатри - } \\
3 \text { особи }\end{array}$} & $\begin{array}{c}\text { Середній } \\
\text { стаж } \\
\text { роботи } \\
\text { (роки) 1-3 }\end{array}$ & $0,46-0,51$ & $0,5-0,57$ & $0,6-0,69$ & $0,68-0,91$ & \\
\hline & & $4-7$ & $0,49-0,55$ & $0,51-0,58$ & $0,61-0,7$ & $0,71-0,86$ & \\
\hline & & $8-10$ & $0,49-0,56$ & $0,53-0,58$ & $0,63-0,73$ & $0,71-0,83$ & \\
\hline
\end{tabular}

Висновки. Аналіз отриманих результатів дозволяє визначити наступні тенденції:

1. Рівень суб'єктивності оцінок у хворих, як в цілому, так і в деяких випадках значно більший, ніж у лікарів, що логічно і зрозуміло.

2. «Завищеність» оцінок хворими пропорційна їх віку, що також логічно і зрозуміло. Аналогічно, як і те, що завдяки більшій емоційній стійкості жінок при оцінюванні власного здоров'я діапазон їх оцінок у цілому менший, ніж у чоловіків.

Достатньо значний розкид оцінок у лікарів обумовлений по-перше, їх фаховою направленістю, по-друге - стажем і досвідом роботи.

\section{Література}

1. Тигранян Р. А. Стресс и его значение для организма /

Р. А. Тигранян. - М. : Наука, 1988. - 176 с.

2. Передирій В. Г. Стрес і його наслідки / В. Г. Передирій,

М. М. Безюк. - К. : НМУ, 2003. - 215 с.

3. Психология эмоций / под. ред. В. К. Вилюнаса,

Ю. Б. Гиппенрейтер. - М. : МГУ 1984. - 288 с.

4. Соколова Е. Д. Эмоциональный стресс: психологические механизмы, клинические проявления, психотерапия / Е. Д. Соколова, - №1 (9). - С. 5-25. 